\title{
Actuator Device
}

National Cancer Institute

\section{Source}

National Cancer Institute. Actuator Device. NCI Thesaurus. Code C49807.

A device designed to automate an action. 